\title{
MANAGEMENT OF CHANGES IN BUSINESS PROCESSES: AN EMPIRICAL STUDY IN SLOVAK ENTERPRISES
}

\author{
ANDREA SUJOVÁ, ONDREJ REMEŇ
}

\begin{abstract}
A B S T R A C T
Constant change is typical of the current business environment. The ability to manage change is a highly appreciated managerial skill. Being adaptive has become a new competitive advantage of a company. Appropriately and successfully implemented changes can improve corporate performance. This paper aimed to evaluate how Slovak companies had been dealing with change in recent years; whether they had been prepared for it; what tools, methods and concepts they had used; and what ultimately had necessitated them from an economic point of view. The paper explored the current status of change management in the context of business processes particular to Slovak enterprises. A literature review concerning change and process management was provided in order to design appropriate research. The research focused on the level of process-oriented management of change in Slovak enterprises operating in different industrial sectors. The main research method was primary quantitative research via questionnaires. Outputs from the questionnaires were subsequently evaluated by contingency tables and the chi-square test which determined the level of significance via $p$-value. Research results presented in this paper confirmed a positive influence of business process change on process maturity and corporate performance. The paper contributed to the development of knowledge in the field of change management, namely, process-oriented change management. The creation of a change-based maturity model for enterprises was identified as a new direction for future work with practical implications.
\end{abstract}

Corresponding author:

Andrea Sujová

Technical University in Zvolen, Faculty of Wood Science and Technology, Department of Business Economics, Slovakia e-mail: sujova@tuzvo.sk

Ondrej Remeň

Technical University in Zvolen, Faculty of Wood Science and Technology, Department of Business Economics, Slovakia e-mail: xremen@tuzvo.sk

\section{INTRODUCTION}

Within a modern enterprise, change is a constant process that can be managed and predicted. Business changes should not respond to changes in the environment, but the changes in the environment should be preceded. A frequency of change increases constantly. Although it is not possible to control all changes, the respective reaction can be managed and controlled. In response to the need of change in the business environment, change management as a managing task becomes one of the crucial operational and strategic conceptions for enterprises that want to achieve sustainable growth and the required level of competitiveness. Change management has been addressed by several authors. One of the most important efforts is by Kotter $(2002 ; 2012)$ who pub- 
lished several bestsellers on leading change with a focus on leadership as well as psychological and social aspects of change management. From a methodological viewpoint, the change management process has been analysed by Armstrong (2008), Passenheim (2010), Drdla and Rais (2001), Kubickova and Rais (2012), Borovský (2005), Zauskova et al. (2013). The authors presented models consisting of a different number of steps.

However, change is two-faceted. The positive side of change is represented by a new opportunity, a chance for a new competitive advantage. The negative side, however, means a certain degree of uncertainty or, to put it otherwise, risks. Enterprises implement every change aiming to improve the future state of the business. Each case may have different improvement areas, yet the goal remains the same, namely, to sustain the business performance. Many authors agree on several available methods and tools focused on corporate performance measurement and management. Deficiencies of traditional performance management and measurement systems have been resolved through additional methods focused on business processes (Fauzia et al., 2017).

The influence of process management on corporate performance has been observed by Sujová and Marcineková (2014; 2015a; 2015b). It has been found that management of processes affects the level of corporate performance. Therefore, an investigation into change management in the context of business processes is plausible.

The current state of change management in Slovakia should be determined to better understand its development. This paper provides an evaluation of how Slovak companies have been dealing with changes in business processes during recent years; whether they have been prepared for it; what tools, methods and concepts they have used; and what ultimately has necessitated them from an economic point of view. Evaluation of data obtained from primary research of questionnaires by way of statistical methods in pursuit of statistical dependences enabled the verification of a hypothesis that changes in business processes had a positive influence on the profitability and economy in companies.

\section{LITERATURE REVIEW}

Change management is a process aimed at ensuring the readiness of an organisation for change and the development of steps required for the change to be accepted and smooth (Armstrong, 2008). According to Demichela et al. (2017), even approaches to change management usually entail a risk-based decision-making strategy; thus, it is usually not enough to verify whether the modification of the process, equipment, or procedure can increase the prior level of risk and failure. This statement was fundamentally argued by Cao et al. (2003) who described change as a dynamic process encompassing different but interrelated forms of diversity. The Slovak business environment contains diverse change. Consequently, Fricova and Cepelova (2014) indicated change management as one of the most common topics of discussion in Slovakia. The variety of change stems from the uniqueness of every enterprise. As every entity has a distinct set of weaknesses and strengths, change can take different forms and occur in different areas, such as market conditions, process management, technological innovations, workforce demographics and diversity, an increased focus on customer and quality, economic environment, or shortage of talent.

Studies from different authors have shown a low success rate of change processes. According to Beer and Nohria (2000), the percentage of successful change implementation amounts to $30 \%$. Also, the success rate may be significantly influenced by various fail factors that can take down the value of successfully performed changes to no more than $7 \%$. The influence of a fail factor depends on the nature of the business, but the most common fail cases are caused by people and their resistance to organisational change (Kotter, 1995; Lines et al., 2015; Aleksic, Zivkovic \& Boskovic, 2015; Božic \& Rajh, 2016). Dobrovič and Timková (2017) state that enterprises often face obstacles to change management, such as inadequate planning, the absence of employee training in the respective field, insufficient time to adapt, employee resistance, inappropriate corporate culture lacking in checks and verifications within the change process, which can easily disrupt smooth implementation of change.

According to Sujová, Marcineková and Hittmar (2017), measuring, assessment, control, and further optimisation of internal processes are presumptions of effective change management and sustainable enterprise improvement. Vickery, Dröbe, Markland (1997) and Leong et al. (1990) claim that the growth of an enterprise is determined by a set of priorities that include flexibility. Process flexibility is an ability of an enterprise to rapidly adapt to changes in the product mix, which is one of the main priorities 
for growing the potential. Several authors name five key dimensions of an effective business process, including costs, delivery efficiency, quality, flexibility and innovation.

However, it is still difficult to manage business processes as basic enablers of an organisation's existence. One of the primary reasons for this complexity arises from the diversity of concepts used under the title of Business Process Management, such as Business Process Reengineering, Process Innovation, and Business Process Automation/Workflow Management (Rosemann et al., 2005). The most common challenges are found in areas of process modelling, process optimisation and business process maturity, which is defined as a state of being complete, perfect and ready, or else characterised as the level of process management.

In their work, Heller and Varney (2013) illustrated the basic levels of the business process maturity and the maturity gap (Fig. 1). Maturity models have five basic levels: initial, defined, organised, managed and optimised.
In the process maturity model, Level One is characterised by non-organised processes, where the output of the process is ensured by the actions and efforts of workers rather than unsecured processes. Enterprises often abandon processes; they are unable to repeat past successes. At Level Two, projects are planned, performed, measured, and controlled. Generally, processes are not extended beyond a department or business unit, and there is often little or no executive support. Level Three means that an organisation utilises processes that are defined, understood and documented through procedures, tools, and methods. Management takes place throughout the whole enterprise and processes are qualitatively predictable, but, generally, there are no enforcement measures. At Level Four, sub-processes contribute to the overall performance. They are controlled using statistical and other quantitative techniques, and performance is both controlled and predictable. At this top maturity level, processes are continually improved based on quantitative measures of common causes of variation in processes.

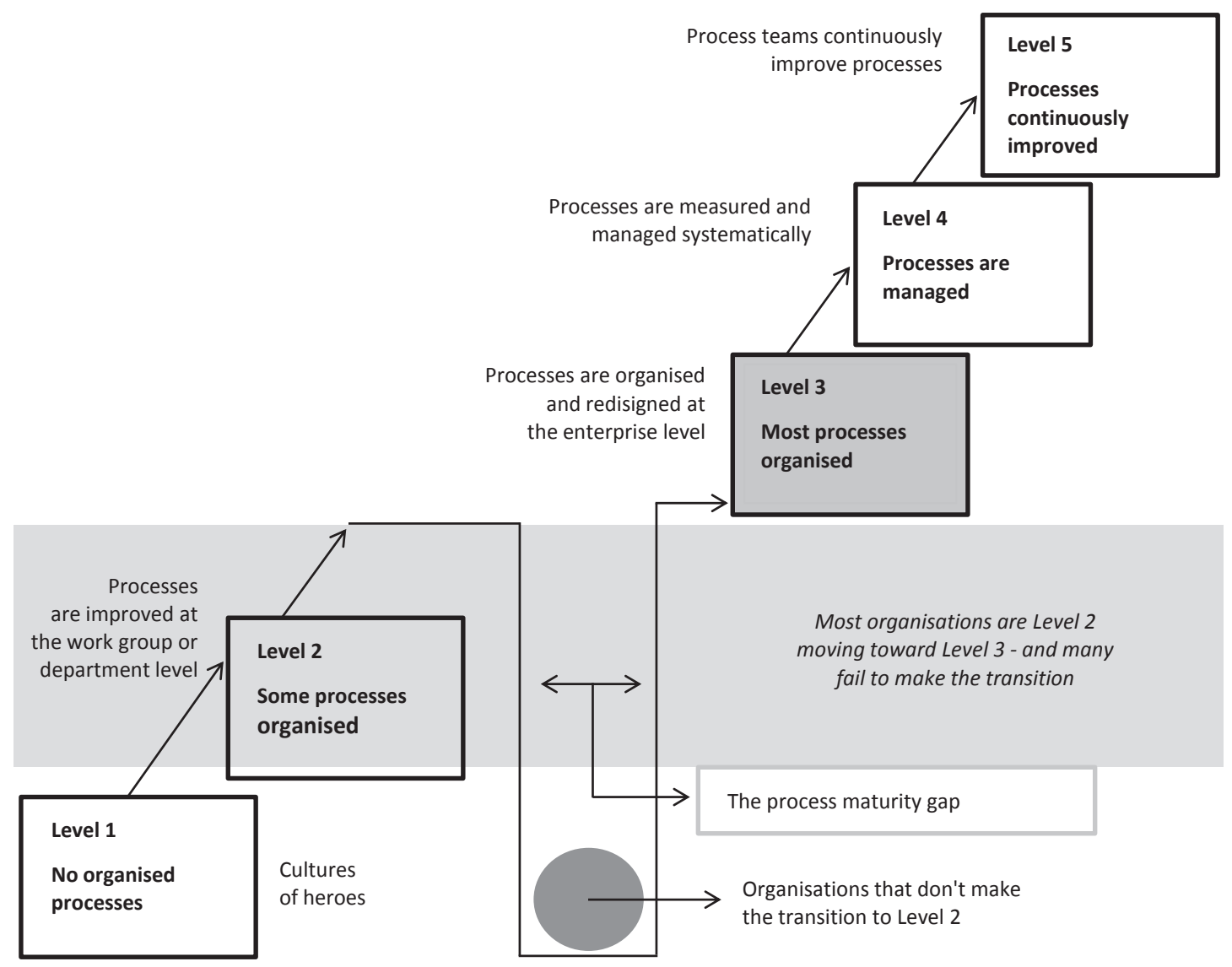

Fig. 1. Process maturity and the maturity gap

Source: (Heller \& Varney, 2013). 
An organisation rapidly responds to changes and opportunities, and it openly shares learning and knowledge. Continuous improvement is a part of all employee roles (Heller \& Varney, 2013). The maturity level of process optimisation should represent one of the main goals for enterprises, namely, the increase in the performance and the reduction of costs.

Process modelling is a fundamental activity for the understanding and communication of process information, and often a prerequisite for conducting analysis, redesign and automation (Dumas et al., 2013). As such, process models are used for many purposes, including increasing understanding of a process by knowledge workers, executing a process, sharing process information with customers, or for what-if analysis (Pinggera, 2014; Recker et al., 2009). However, in order to successfully serve potential uses, models should be understandable to their audience. Therefore, it is necessary and recommended to model the process and try to find the best solution before implementing any change.

Changes in business processes follow process improvement. According to defined defaults in processes, radical or optimising change can be proposed. Radical changes are represented by Business Process Reengineering defined by Hammer and Champy (2000) as a radical change of business processes in pursuit of dramatic performance improvement. The main principle of reengineering is the identification of outdated rules, methods and processes, and their radical change to new and more effective ones. The second extensive change is restructuration as a transformation change.

Optimisation of processes includes all activities aimed at improving the efficiency. This can be related to the use of the company's production resources with the possibility to accelerate the production process, to efficiently exploit the production potential, to increase revenues, to reduce production costs, and to better control the production process (Rut, 2017). Finding the optimal solution while maintaining the desired product quality level means to reduce important factors in the business process, including material and energy consumption, product development costs and time. Changing variables in process modelling results in a reduction in material inputs, production costs, shape, material properties of a product and a minimised optimisation task value at the end of the process (Sujová, Marcineková \& Simanová, 2016). Sujová and Marcineková (2015a) define the best-known concepts and methods for process optimisation as follow: Balanced Scorecard (BSC), Six Sigma, Activ- ity Based Costing (ABC), European Foundation for Quality Management (EFQM), Total Quality Management (TQM), Total Productive Maintenance (TPM), Kaizen, Method 5S, ISO Norms, Benchmarking, and Process controlling.

Many organisations realise the importance of business processes in delivering high-quality products and services (Indulska et al., 2009). Prevention of a decrease in quality during production as well as supportive and operational processes are the main target for achieving operative quality management, and the most commonly used method is measurement and evaluation of the process capability (Simanová \& Gejdoš, 2015). Gejdoš and Simanová (2017) believe that fluctuation of the quality mark values is a natural part of the process. Even though it is impossible to achieve its absolute uniformity, it is necessary to monitor this value as systematic causes in the production process can result in the process with variability values so diversified that its performance would be very low, with defects in output, increasing overall costs and unproductive losses. Consequently, the implementation of the processoriented management of changes can be considered in this area as a complicated, demanding and challenging task.

\section{RESEARCH METHODS}

The main research method was primary quantitative research conducted using questionnaires. The research focused on the level of process-oriented management of change in Slovak enterprises operating in different industrial sectors. The first database of enterprises comprised the data of the Statistical Office of the Slovak Republic, which was subsequently verified by Internet databases in order to select existing companies. The core sample or the population size (N) of the survey amounted to 2525 enterprises. A representative sample (n) consisted of 524 enterprises, which was also the number of completed questionnaires. According to the calculation of the minimum statistical research sample, it was a representative sample at $99 \%$ confidence and $4 \%$ of the standard deviation. It should be noted that $\mathrm{N}$ represents the population size, $r$ is the fraction of responses, $Z(c / 100)$ represents the critical value for the confidence level $c$.

The questionnaire consists of five general classification questions and 30 business-area management 
issues. The questionnaire was published online, and the data collection took place in the first half of 2017.

Enterprises were interviewed directly using a structured interview and indirectly via e-mail communication with managers. Answers from the questionnaire were processed and evaluated by way of a chosen statistical method: descriptive statistics, contingent method, and a chi-squared test. A chisquared statistic was used to calculate a p-value to the chi-squared distribution.

Chi-squared is a Pearson's cumulative test statistic; Oi is an observed frequency, Ei is the expected frequency (theoretical) asserted by the null hypothesis, and $\mathrm{n}$ is the number of cells in the table. The outcome p-value helped to confirm or deny the primary hypotheses between the selected questions.

The hypotheses for the evaluation of relationships between selected question pairs were determined as presented in Tab. 1 .

\section{RESEARCH RESULTS}

This part of the paper presents selected results of the primary research conducted through an online questionnaire. In the first step, data of general classification questions were analysed by descriptive statistical tools. The results presented in Tab. 2 help to improve the understanding of the nature of the representative sample.

According to the first part of Tab. 2, judging by the average number of employees, the sample consisted of small to large enterprises. The largest group in the sample comprised of enterprises with the average number of employees ranging from 0 to 10 with the response frequency of 237 , which represented $45.2 \%$ of the total sample. In conclusion, the Slovak business environment is dominated by small businesses.

The second part of the table presents the structure of the capital in the analysed enterprises. As data suggest, even though Slovakia has been a part of the EU for ten years, foreign investments are rarely channelled to smaller enterprises that could contribute to the growth of the gross domestic product. It seems that foreign investors are not interested in Slovak small businesses. There are two possible reasons:

- Slovak small enterprises and the related business environment (legislation, competition, availability of qualified workforce etc.);

- limited management skills and appetite for change (missing strategic leadership) leading to the little incentive for change versus strategic behaviour of investors to ignore small enterprises.

The last part of the table analysed the ROE score. From the total number of enterprises that took part in the survey, $91.6 \%$ had a positive ROE score in 2015. However, more than $56 \%$ of the sample reached ROE up to $4 \%$.

The next part of this paper focuses on the analysis via contingencies and the chi-square test in order to verify the existence of relations between the selected survey questions regarding changes in business processes.

The first cross-table (Tab. 3) provides the analysis and evaluation of questions Q4: "What types of

Tab. 1. Main hypotheses of the research

THE RELATION BETWEEN THE USE OF NEW CONCEPTS AND METHODS FOR PROCESS IMPROVEMENT AND THE LEVEL OF PROCESS OPTIMISATION (Q6-Q14)

1 HO: The use of new process management concepts and methods does not influence on the level of optimisation (business process maturity)

$\mathrm{H} 1$ : The use of new process management concepts and methods influences the level of optimisation (business process maturity)

THE RELATION BETWEEN THE USE OF MODELS FOR PROCESS OPTIMISATION AND THE LEVEL OF PROCESS OPTIMISATION (Q6-Q16)

2 HO: The level of process optimisation does not depend on the use of at least one model for analysis and optimisation of processes

$\mathrm{H} 1$ : The level of process optimisation depends on the use of at least one model for analysis and optimisation of processes

THE RELATION BETWEEN THE ACHIEVED ROE VALUE AND THE LEVEL OF PROCESS OPTIMISATION (Q6-QD)

3 HO: There is no statistical dependence between the individual levels of process optimisation and ROE reached H1: A statistical dependence exists between the individual levels of process optimisation and the reached ROE

THE RELATION BETWEen CHANGES MADE AND ANALYSIS CARRIED OUT BEFORE THE CHANGE PROCESS (Q11-Q4)

$\mathrm{HO}$ : There is no significant dependence between the change type and the performed analyses made before or in its preparation.

4 In other words, specific changes do not require specific analysis before executing

H1: A significant dependence exists between the change type and the performed analyses made before or in its preparation. In other words, specific changes do require specific analysis before executing 
Tab. 2. Descriptive statistics of the survey (relative and absolute frequencies) from a total of 524 enterprises

\begin{tabular}{|l|r|r|}
\hline \multicolumn{2}{|c|}{ OBSERVED FREQUENCIES QUESTION A: “WHAT IS THE AVERAGE NUMBER OF EMPLOYEeS IN YOUR ENTERPRISE?” } \\
\hline 0 to 10 employees & $45.23 \%$ & 237 \\
\hline 11 to 20 employees & $12.40 \%$ & 65 \\
\hline 21 to 50 employees & $14.12 \%$ & 74 \\
\hline 51 to 250 employees & $15.08 \%$ & 79 \\
\hline over 250 employees & $13.17 \%$ & 69 \\
\hline \multicolumn{1}{|c|}{ OBSERVED FREQUENCIES QUESTION C: “WHAT IS THE OWNERSHIP OF YOUR ENTERPRISE?” } \\
\hline net domestic capital & $70.80 \%$ & 371 \\
\hline the domestic capital prevails & $16.41 \%$ & 86 \\
\hline foreign capital prevails & $7.44 \%$ & 39 \\
\hline net foreign capital & $5.34 \%$ & 28 \\
\hline \multicolumn{1}{|c|}{ OBSERVED FREQUENCIES QUESTION D: “WHAT WAS THE ROE OF YOUR COMPANY IN 2015?” } \\
\hline negative value / ROE < 0 & $8.40 \%$ & 44 \\
\hline positive value - from 0\% to 2\% & $24.24 \%$ & 127 \\
\hline positive value - from 2\% to 4\% & $24.05 \%$ & 126 \\
\hline positive value - from 4\% to 7\% & $21.95 \%$ & 115 \\
\hline positive value - from 7\% to 10\% & $10.31 \%$ & 54 \\
\hline positive value - over 10\% & $11.07 \%$ & 58 \\
\hline
\end{tabular}

Tab. 3. Contingencies Q11-Q4

\begin{tabular}{|c|c|c|c|c|c|c|c|c|c|c|c|c|}
\hline \multicolumn{12}{|c|}{ ANALYSIS BEFORE THE CHANGE } & \multirow[b]{2}{*}{ [\%] } \\
\hline \multirow{21}{*}{ 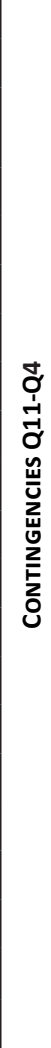 } & \multirow{9}{*}{ 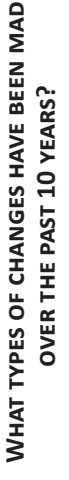 } & OBSERVED & SA & $\mathrm{AP}$ & AFF & FA & AK & $\mathrm{ABP}$ & ASaPZ & Other & total & \\
\hline & & Financial restructuring & 22 & 18 & 12 & 59 & 47 & 20 & 54 & 0 & 232 & 17 \\
\hline & & $\begin{array}{l}\text { Transformational } \\
\text { restructuring }\end{array}$ & 17 & 15 & 4 & 21 & 12 & 9 & 17 & 1 & 96 & 7 \\
\hline & & Radical reengineering & 12 & 9 & 2 & 12 & 15 & 14 & 18 & 0 & 82 & 6 \\
\hline & & Gradual improvement & 63 & 42 & 18 & 139 & 100 & 69 & 129 & 2 & 562 & 42 \\
\hline & & Incremental changes & 23 & 18 & 9 & 58 & 40 & 36 & 56 & 2 & 242 & 18 \\
\hline & & We did not make any changes & 3 & 3 & 6 & 20 & 28 & 8 & 48 & 16 & 132 & 10 \\
\hline & & Total & 140 & 105 & 51 & 309 & 242 & 156 & 322 & 21 & 1346 & \\
\hline & & Proportion [\%] & 10 & 8 & 4 & 23 & 18 & 12 & 24 & 2 & & \\
\hline & & & & & & VALYSIS & EFORE & HE CHA & IGE & & & \\
\hline & 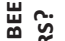 & 201 & SA & AP & AFF & FA & AK & $\mathrm{ABP}$ & ASaPZ & Other & total & [\%] \\
\hline & 崖 & Financial restructuring & 24.1 & 18.1 & 8.8 & 53.3 & 41.7 & 26.9 & 55.5 & 3.6 & 232 & 17 \\
\hline & 눈운 & Transformational restructuring & 10.0 & 7.5 & 3.6 & 22.0 & 17.3 & 11.1 & 23.0 & 1.5 & 96 & 7 \\
\hline & $z_{\leq} \frac{y}{2}$ & Radical reengineering & 8.5 & 6.4 & 3.1 & 18.8 & 14.7 & 9.5 & 19.6 & 1.3 & 82 & 6 \\
\hline & 岌堊 & Gradual improvement & 58.5 & 43.8 & 21.3 & 129.0 & 101.0 & 65.1 & 134.4 & 8.8 & 562 & 42 \\
\hline & 㟧 & Incremental changes & 25.2 & 18.9 & 9.2 & 55.6 & 43.5 & 28.0 & 57.9 & 3.8 & 242 & 18 \\
\hline & そ㟧 & We did not make any changes & 13.7 & 10.3 & 5.0 & 30.3 & 23.7 & 15.3 & 31.6 & 2.1 & 132 & 10 \\
\hline & $\sum^{T} \Sigma$ & Total & 140 & 105 & 51 & 309 & 242 & 156 & 322 & 21 & 1346 & \\
\hline & & Proportion [\%] & 10 & 8 & 4 & 23 & 18 & 12 & 24 & 2 & & \\
\hline & & the expected values are lower $t$ & the & ual & & & & & & & & \\
\hline & & the expected values are higher & In the a & ctual & & & & & & & & \\
\hline
\end{tabular}


changes have been made over the past ten years?" and Q11: "What analyses have been made before implementing the change, in its preparation?" The following abbreviations were used for names of analyses: SA - SWOT analysis, AP - portfolio analysis, AFF - force field analysis (enabling vs deterrent forces for change), FA - financial analysis, AK - analysis of competition, $\mathrm{ABP}$ - analysis of business processes, ASaPZ - satisfaction analysis and customer needs, other. Both questions had multiple answers. The main aim was to determine the existence of a statistical significance between them and to reject or accept the $\mathrm{H} 1$ hypothesis.

According to the results, the most common change was the gradual improvement with the answer frequency amounting to $42 \%$ of the total answers. By this type of change most enterprises meant financial analysis, analysis of competition and customers, and also analysis of business processes. On the other hand, the lowest frequency amounting to $6 \%$ was observed by the radical re-engineering change, which is lower than the frequency of the answer "we did not make any changes", namely, $10 \%$. One interesting finding was enterprises without any change. However, even such enterprises have been making analyses of their financial situation, competition and customer needs.

According to the calculated $\mathrm{p}$-value, $\mathrm{p}=1.94 \mathrm{E}-19$ (0.00000000000000000019398), this dependence is very strong and, therefore, it is possible to refuse the Ho hypothesis and accept the $\mathrm{H} 1$ with almost $100 \%$ significance. In conclusion, the choice to undertake an analysis before implementing a change depends on the type of change.

Tab. 4 analyses the relationship between questions 6 "At what level do you optimise processes?" and 14 "What new concepts and methods have you used to improve processes?". The table uses abbreviations for the new concepts and method names: BS Balanced Scorecard, SS - Six Sigma, PC - Process Controlling, TQM - Total Quality Management, K Kaizen (continuous improvement of business processes), B - Benchmarking, $\mathrm{N}$ - none of the methods and concepts. Enterprises could mark more than one answer in question 14.

As the results suggest, $50.2 \%$ (263 from 524) of enterprises use new concepts and methods to improve processes but still have room for improvement; 7\% have a built-in mathematical model for calculating total costs up to delivery; $15.6 \%$ have modern technology available to create efficient business processes for employees; $15.8 \%$ have business standards and processes linked to the identified business success factors and customer requirements; $10.1 \%$ have a change management programme that ensures employee loyalty; and $15.8 \%$ cannot identify their level of process optimisation. The results also suggest that comparing observed versus expected values of the cell where Q14N and Q6-6 answers cross, the observed value is much higher than statistically expected. Possibly, enterprises that do not use any of the methods and concepts for process improvement do not achieve any level of process optimisation. Compared to the expected statistical frequencies, the number of enterprises that responded to this combination amounted to $53 \%$ of the whole sample, and the total count was $66.3 \%$ higher than expected.

However, this assertion had to be verified statistically by means of a p-value, which was calculated using the chi-square test. The calculated $\mathrm{p}$-value for this table was $p=0.000000426$, so the relationship between the level of process optimisation and the use of new concepts and methods for improvement was statistically significant. Consequently, the hypothesis $\mathrm{H} 0$ could be rejected as $\mathrm{H} 1$ was true, namely, the use of multiple concepts and methods for process improvement had a significant impact on the level of process optimisation. On the other hand, more than $53 \%$ of the enterprises did not use any concept or method to improve their processes.

The next table (Tab. 5) compares the question 6: "At what level do you optimise processes?" with the question 16: "Do you use some of the following models to analyse and optimise processes?". The main aim was to determine if the use of models for analysis and optimisation of processes influenced the level of process optimisation in the surveyed enterprises. The following abbreviations are used in the table: DRM - Diagnostic Reference Models (reference tables, relational databases, OLAP cubes), IM - Information Models (ARIS, Matis, FirstStep, CimTool, IDEF, UML), DS - Dynamic Simulation (integration of fuzzy logic, genetic algorithms), IM - Integrated Methods (GIM, SIM, GI-SIM, IMF-M methodology), DABP - business processes do not get analysed, $\mathrm{O}$ other. Enterprises could mark multiple answers in question 16.

Based on Tab. 5, 46.2\% (242 from 524) of enterprises use models to analyse and optimise processes but still have room for improvement, $1.4 \%$ have a built-in mathematical model for calculating total costs up to delivery, $13.4 \%$ have modern technology available to create efficient business processes for employees, $13 \%$ have business standards and pro- 
Tab. 4. Contingencies Q6-Q14

\begin{tabular}{|c|c|c|c|c|c|c|c|c|c|c|c|c|}
\hline \multirow{2}{*}{\multicolumn{4}{|c|}{ OBSERVED FREQUENCY }} & \multicolumn{9}{|c|}{$\begin{array}{l}\text { 14. WHAT NEW CONCEPTS AND METHODS HAVE YOU USED OR } \\
\text { EMPLOYED TO IMPROVE PROCESSES? }\end{array}$} \\
\hline & & & & BS & SS & PC & TQM & K & B & $\mathrm{N}$ & other & total \\
\hline \multirow{19}{*}{ 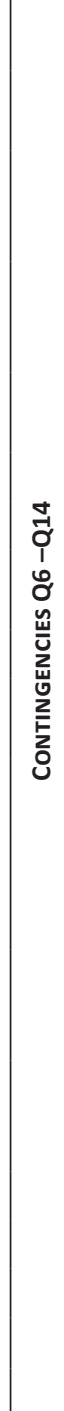 } & \multirow{7}{*}{ 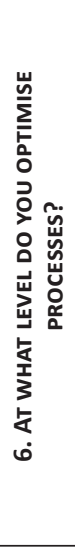 } & 1 & $\begin{array}{l}\text { Optimisation options have been identified } \\
\text { (we know areas that require improvement) }\end{array}$ & 13 & 10 & 37 & 20 & 26 & 21 & 135 & 1 & 263 \\
\hline & & 2 & $\begin{array}{l}\text { We have a built-in mathematical model for } \\
\text { calculating total costs up to delivery }\end{array}$ & 2 & 3 & 3 & 5 & 5 & 7 & 12 & 0 & 37 \\
\hline & & 3 & $\begin{array}{l}\text { Employees have modern technology } \\
\text { available to create efficient business } \\
\text { processes }\end{array}$ & 2 & 3 & 9 & 7 & 10 & 12 & 38 & 1 & 82 \\
\hline & & 4 & $\begin{array}{l}\text { Business standards and processes are } \\
\text { linked to the identified business success } \\
\text { factors and customer requirements }\end{array}$ & 4 & 2 & 13 & 12 & 8 & 7 & 37 & 0 & 83 \\
\hline & & 5 & $\begin{array}{l}\text { We have a change management } \\
\text { programme that ensures employee loyalty }\end{array}$ & 3 & 2 & 7 & 8 & 2 & 7 & 23 & 1 & 53 \\
\hline & & 6 & None of these options applies & 0 & 0 & 0 & 2 & 4 & 0 & 73 & 4 & 83 \\
\hline & & & Total & 24 & 20 & 69 & 54 & 55 & 54 & 318 & 7 & 601 \\
\hline & \multirow{2}{*}{\multicolumn{3}{|c|}{ Expected frequency }} & \multicolumn{9}{|c|}{$\begin{array}{l}\text { 14. WHAT NEW CONCEPTS AND METHODS HAVE YOU USED OR } \\
\text { EMPLOYED TO IMPROVE PROCESSES? }\end{array}$} \\
\hline & & & & BS & SS & PC & TQM & K & B & $\mathrm{N}$ & other & total \\
\hline & \multirow{7}{*}{ 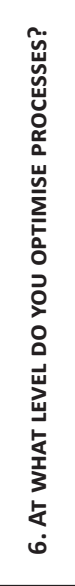 } & 1 & $\begin{array}{l}\text { Optimisation options have been identified } \\
\text { (we know areas that require improvement) }\end{array}$ & 10.5 & 8.8 & 30.2 & 23.6 & 24.1 & 23.6 & 139.2 & 3.1 & 263 \\
\hline & & 2 & $\begin{array}{l}\text { We have a built-in mathematical model for } \\
\text { calculating total costs up to delivery }\end{array}$ & 1.5 & 1.2 & 4.2 & 3.3 & 3.4 & 3.3 & 19.6 & 0.4 & 37 \\
\hline & & 3 & $\begin{array}{l}\text { Employees have modern technology } \\
\text { available to create efficient business } \\
\text { processes }\end{array}$ & 3.3 & 2.7 & 9.4 & 7.4 & 7.5 & 7.4 & 43.4 & 1.0 & 82 \\
\hline & & 4 & $\begin{array}{l}\text { Business standards and processes are } \\
\text { linked to the identified business success } \\
\text { factors and customer requirements }\end{array}$ & 3.3 & 2.8 & 9.5 & 7.5 & 7.6 & 7.5 & 43.9 & 1.0 & 83 \\
\hline & & 5 & $\begin{array}{l}\text { We have a change management } \\
\text { programme that ensures } \\
\text { employee loyalty }\end{array}$ & 2.1 & 1.8 & 6.1 & 4.8 & 4.9 & 4.8 & 28.0 & 0.6 & 53 \\
\hline & & 6 & None of these options applies & 3.3 & 2.8 & 9.5 & 7.5 & 7.6 & 7.5 & 43.9 & 1.0 & 83 \\
\hline & & & Total & 24 & 20 & 69 & 54 & 55 & 54 & 318 & 7 & 601 \\
\hline & & & Proportion [\%] & 4 & 3 & 11 & 9 & 9 & 9 & 53 & 1 & \\
\hline & & & the expected values are lower than the actu & ones & & & & & & & & \\
\hline & & & the expected values are higher than the ac & ones & & & & & & & & \\
\hline
\end{tabular}

cesses linked to the identified business success factors and the customer requirements, $8.2 \%$ have a change management programme that ensures employee loyalty, and $16 \%$ cannot identify their level of process optimisation. While most enterprises reported Levels Four and Five of process maturity, they can hardly be considered mature enough due to observed overlapping features of Levels One to Three.

In most cases, no model is used, and in exceptional use cases, it is a simple model based on a Diagnostic Reference Method. Diagnostic Reference Models are also used by enterprises at process maturity Levels One and Three.
The comparison of observed and expected frequencies demonstrated a result very similar to the previous analysis. Therefore, it is possible to conclude that enterprises without models for process analysis and optimisation achieve no process optimisation. The p-value for this table (Tab. 5) amounts to $\mathrm{p}=0.000167445$, which means the H0 hypothesis is rejected while the $\mathrm{H} 1$ hypothesis holds true. It follows that using models for process analysis and optimisation is important to reach a higher level of process maturity.

Tab. 6 analyses the relationship between the level of process optimisation and ROE. The analysis aimed to determine if the level of process optimisation 


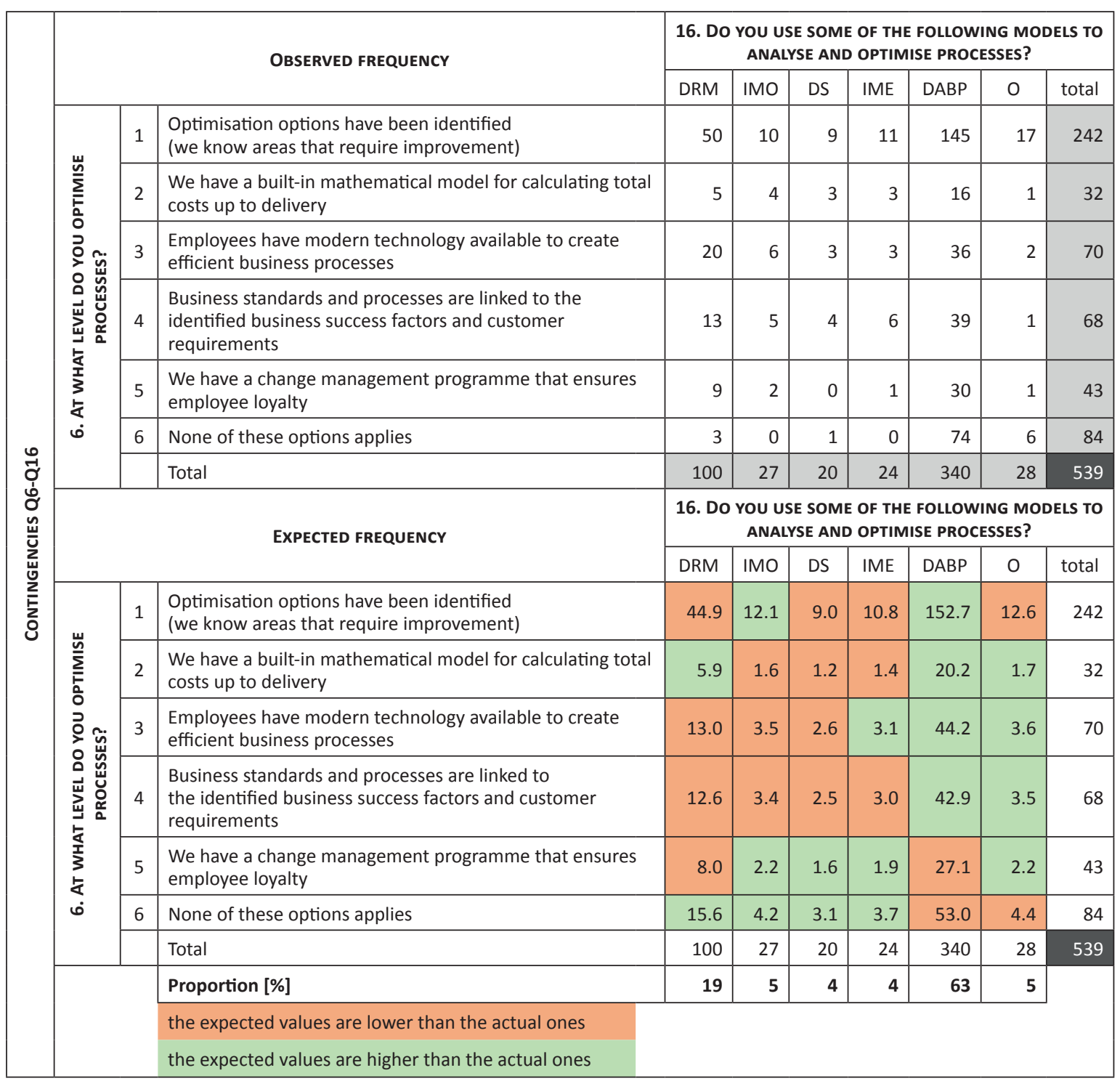

influenced the ROE of the surveyed enterprises. According to the comparison of expected and observed frequencies in Tab. 6, a higher than expected observed value for the option "Optimisation options have been identified (we know areas that require improvement)" was among enterprises with ROE from $4 \%$ to over $10 \%$ and a superior process. This finding suggests that such enterprises are better at eliminating bottlenecks because they have either optimised processes already or have no knowledge/ information about processes that could be optimised. However, the positive ROE result means that the first option - the processes have already been optimised - is more likely. Enterprises with ROE 0\% - 2\% either have optimisation possibilities identified or prefer modern technology for employees. Enterprises with
ROEs $4 \%-7 \%$ and $7 \%-10 \%$ are most mature, and their observed frequencies are higher than expected in 4 different levels of process optimisation.

The $\mathrm{p}$-value for this table is $\mathrm{p}=0.0480$, making this dependence statistically significant. This means that the $\mathrm{H} 0$ hypothesis is rejected, while the $\mathrm{H} 1$ hypothesis holds true. Furthermore, the optimising tools and their use has a significant influence on the ROE. Table 6 clearly suggests that enterprises with a negative ROE score either use none of these tools or know about process-related issues yet take no action.

The last figure (Fig. 2) shows that many enterprises with the ROE value $0-7 \%$ much more regularly monitor processes than the enterprises with the ROE value $7 \%-10 \%$. This finding can be explained by an assumption that enterprises with 
Tab. 6. Contingencies Q6-QD

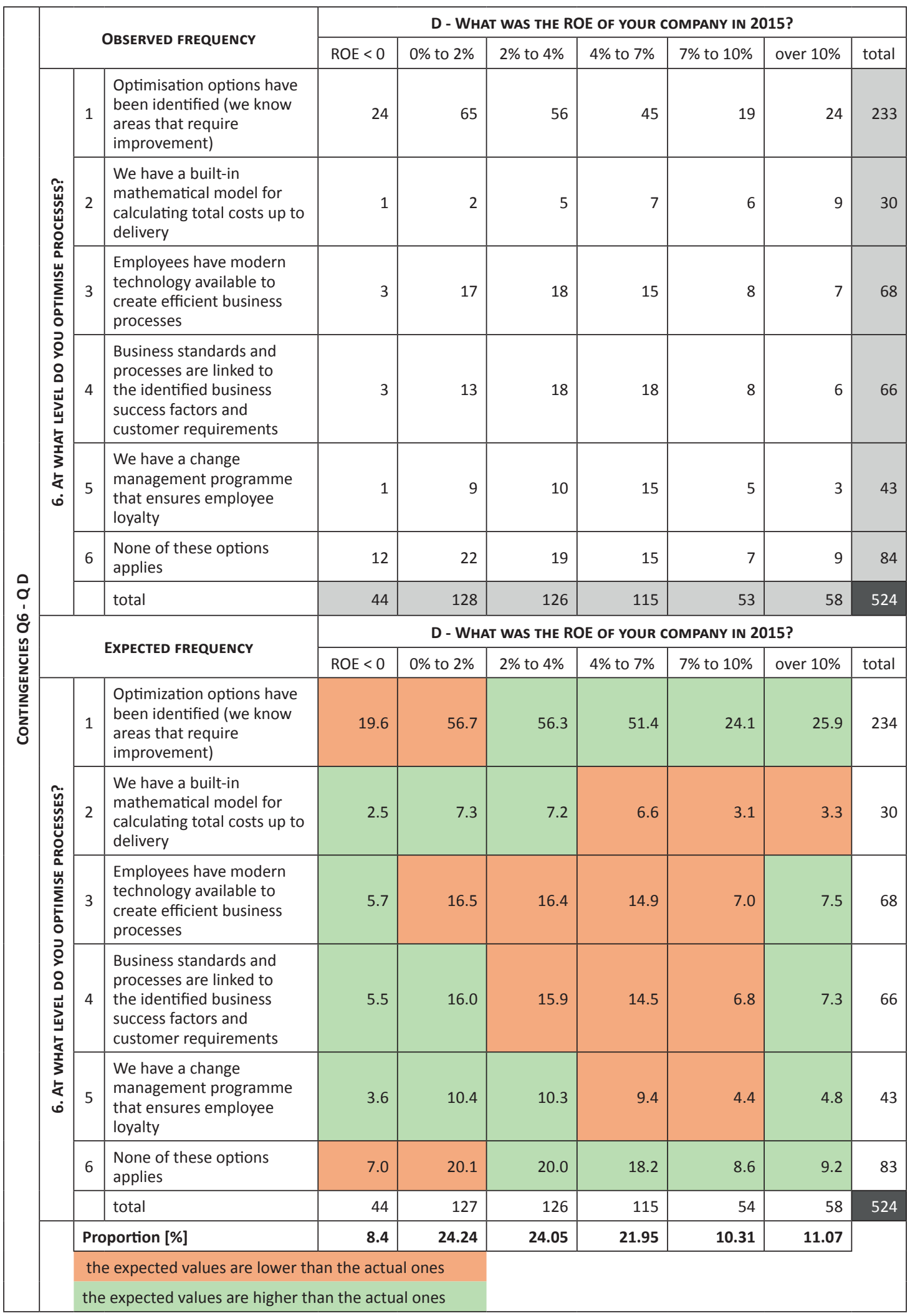




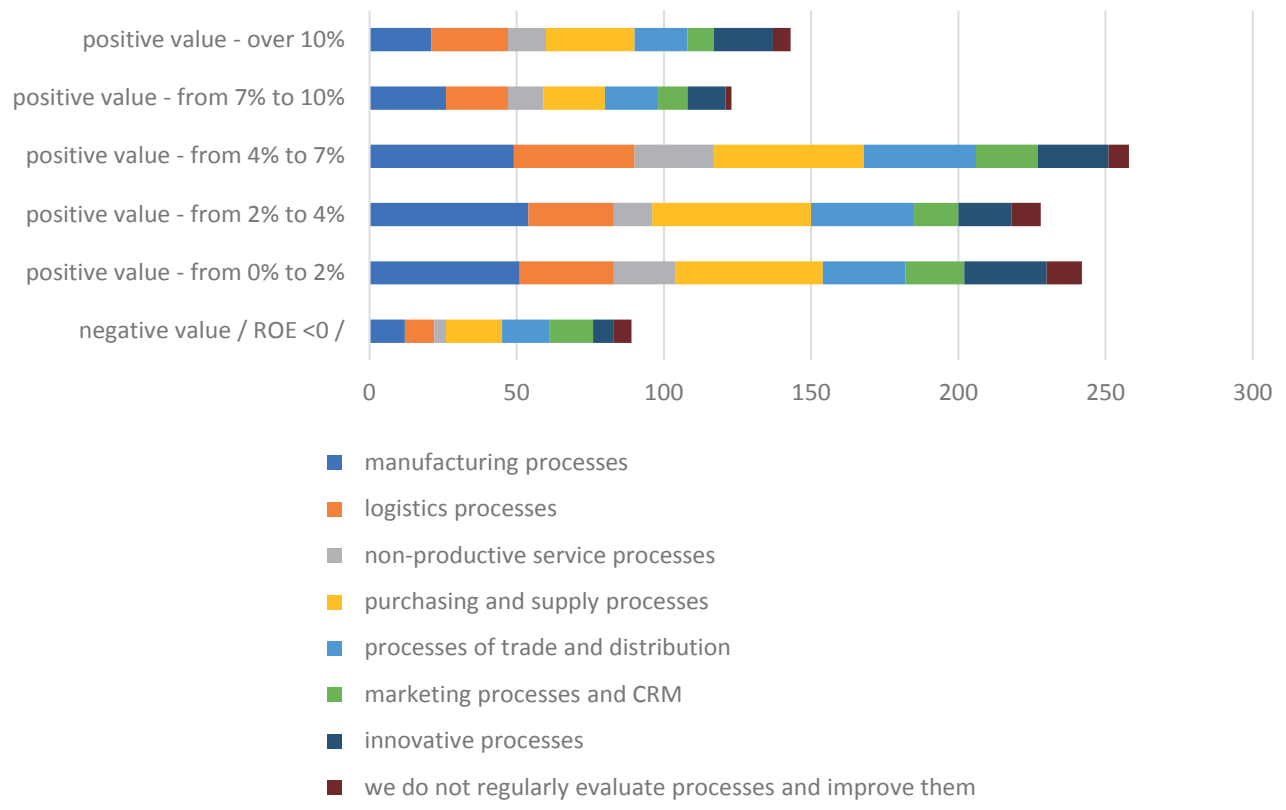

Fig. 2. Regularly monitored processes divided by enterprise ROE

a lower ROE have not reached a higher maturity level of process optimisation and, therefore, must allocate much more attention and financial means to process monitoring, which could be a reason of a smaller ROE value.

\section{DISCUSSION OF THE RESULTS}

Previous research used the Capability Maturity Model (CMM) to describe the degree, to which an organisation applies formalised processes to the management of its various business functions (Marcineková \& Sujová, 2015a; 2015b). The popularity of this model is growing; it gets implemented in different process areas. The CMM integration in management aims to improve the level of processes. This study demonstrated that the model could be considered for adoption by many Slovakian enterprises but mainly small businesses. This research also revealed possibilities to implement process-oriented change management under Slovak market conditions and confirmed the result of another research (Sujová \& Marcineková, 2014) stating that a low level of process management (maturity) is typical of enterprises with lower performance. A qualitative level of process management has a direct influence on corporate performance. We can also assume that the overall level of maturity in Slovak enterprises corresponds to the findings, and the calculated p-value has a signifi- cant relationship with the use of new methods and models in the field of process improvement. A positive impact on corporate performance made by modern methods for business process management was also confirmed by Marcinekova and Sujova (2015a). The research also indicated that process controlling, Kaizen, TQM and benchmarking were among methods mostly used by small Slovak enterprises. However, many enterprises (almost 50\%) did not use any modern method (Sujova \& Marcinekova, 2015b).

The mentioned findings lead to a conclusion that aiming for higher corporate performance, Slovak enterprises should focus on the improvement of internal processes using modern conceptions and management methods. Process improvement requires greater attention to process analysis. The research indicated that $63 \%$ of enterprises do not analyse processes at all. Besides, the existing competition gap should be used by small enterprises as an opportunity for future development of performance growth.

\section{CONCLUSIONS}

The quantitative research focused on change management and its impact on the business success (economics) of enterprises operating in Slovakia. The research results suggest that change management has a major positive influence on Slovak enterprises. According to the multiple cross-table analyses, 
the contingency method and the chi-square test p-value statistically confirmed that the implementation of new concepts and methods of process improvement could increase the existing maturity level of process optimisation. Even though many companies do not optimise processes at all, there is a large group of enterprises that have successfully crossed the maturity gap between Levels Two and Three. Results also confirmed a positive influence of models used for process optimisation analysis. Besides, the achieved level of maturity influences the ROE indicator. The relationship between changes and analysis means that a proper analysis can uncover business process areas that require improvement. In summary, the ROE mirrors efforts of Slovak enterprises in the field of process optimisation. Therefore, enterprises should focus their efforts on a "level jump" aiming to achieve the highest possible process maturity level for staying competitive and profitable, which are the crucial survival criteria.

The presented research and its results contributed to the development of a new approach to change management, namely, process-oriented management of change. It was confirmed, that effective changes should be managed based on process principles and focused on the improvement of business processes. This is the way towards sustainable corporate performance.

The research also revealed a new direction for future scientific work, including practical implications, consisting of the development of a new changebased maturity model for smaller enterprises using larger successful enterprises as a benchmark.

However, caution is required in the adjustment of the maturity model for small enterprises against large firms (benchmark) as stated in the paper, the approach to change is complicated, demanding and challenging. Therefore, change management capability gaps should be viewed as the business environment complexity particular to small enterprises and different from large companies.

\section{ACKNOWLEDGEMENTS}

The paper is a partial result of the research project VEGA 1/0286/16 - Change management based on a process approach.

\section{LITERATURE}

Aleksic, V. S., Zivkovic, S., \& Boskovic, A. (2015). Organizational Change Resistance: Experience from Public Sector. Journal of Economic and Social Development, 2(1), 109-124.

Armstrong, M. (2008). Management and leadership. Prague, Czechia: Grada Publishing.

Beer, M., \& Nohria, N. (2000). Cracking the Code of Change. Harvard Business Review, 78(3), 133-148.

Borovský, J. (2005). Manažment zmien - cesta $k$ rastu konkurencieschopnosti [Management of Change the way to cometitiveness increase]. Bratislava, Slovakia: Eurounion.

Božić, L., \& Rajh, E. (2016). The Factors Constraining Innovation Performance of SMEs. Economic Research-Ekonomska Istraživanja, 29(1), 314-324. doi: 10.1080/1331677X.2016.1168040

Cao, G. M., Clarke, S., \& Lehaney, B. (2003). Diversity Management in Organizational Change: Towards A Systemic Framework. Systems Research and Behavioral Science, 20(3), 231-242.

Demichela, M., Baldissone, G., \& Camuncoli, G. (2017). Risk-Based Decision Making for the Management of Change in Process Plants: Benefits of Integrating Probabilistic And Phenomenological Analysis. Industrial \& Engineering Chemistry Research, 56(50), 14873-14887. doi: 10.1021/acs.iecr.7b03059

Dobrovic, J., \& Timkova, V. (2017). Examination of Factors Affecting the Implementation of Organizational Changes. Journal of Competitiveness, 9, 5-18. doi: 10.7441/joc.2017.04.01

Drdla, M., \& Rais, K. (2001). Řizení změn ve firmě - reengineering [Management of Changes in a firm - reengineering]. Prague, Czechia: Computer Press.

Dumas, M., La Rosa, M., Mendling, J., \& Reijers, H. A. (2013). Fundamentals of Business Process Management. New York, USA: Springer.

Fauzia, S., Budiningsih, I., Djaelani, A., \& Ahmad, M. (2017). Dominant factors affecting the behavior of innovative employees. Polish Journal of Management Studies, 16(1), 32-40.

Fricova, D., \& Cepelova, A. (2014). Process Management and Process Modelling in Territorial Self-Government of Slovakia. Proceedings from International Multidisciplinary Scientific Conferences on Social Sciences and Arts, 311-318.

Gejdos, P., \& Simanova, L. (2017). Modern Methods of the Quality Improvement and Their Application in Managing of Changes in a Company. New Trends and Issues Proceedings on Humanities and Social Sciences, 4(10), 64-72.

Hammer, M., \& Champy, J. (2000). Reengineering - radikální promèna firmy [Reengineering - a radical change of a Firm]. Prague, Czechia: Management Press.

Heller, A., \& Varney, J. (2013). Using Process Management Maturity Models. Huston, USA: APQC. 
Indulska, M., Recker, J., Rosemann, M., \& Green, P. (2009a). Process modelling: current issues and future challenges. Proceedings of European Conference on Information System, 501-514.

Indulska M., Recker J., Rosemann M., \& Green P. (2009b). Business Process Modeling: Current Issues and Future Challenges. In P. van Eck, J. Gordijn, R. Wieringa (Eds.), Advanced Information Systems Engineering (pp. 501-514). Berlin, Germany: Springer.

Kotter, J. P. (1995). Leading Change: Why Transformation Efforts Fail. Harvard Business Review, 73(2), 59-67.

Kotter, J. P. (2012). Leading Change. Boston, USA: Harvard Business School Press.

Kotter, J. P., \& Cohen, D. S. (2002). The heart of Change. Boston, USA: Harvard Business School Press.

Kubíčková, L., \& Rais, K. (2012). Řizení změn ve firmách a jiných organizacích [Change management in firmas and other organizations]. Prague, Czechia: Grada Publishing.

Leong, G. K., Snyder, D. L., \& Ward, P. T. (1990). Research in the Process and Content of Manufacturing Strategy. Omega International Journal Management Science, 18, 109-122.

Lines, B. C., Sullivan, K. T, Smithwick, J. B., \& Mischung, J. (2015). Overcoming Resistance to Change in Engineering and Construction: Change Management Factors for Owner, Organizations. International. Journal of Project Management, 33(5), 170-1179. doi: 10.1016/j.ijproman.2015.01.008

Passenheim, O. (2010). Change management. Telluride, USA: Ventus Publishing.

Pinggera, J. (2014). The Process of Process Modelling. Innsbruck, Austria: University of Innsbruck.

Recker, J., Rosemann, M., Indulska, M., \& Green, P. (2009). Business process modelling - a comparative analysis. Journal of the Association for Information Systems, 10(4), 333-363.

Rosemann, M., \& Bruin, T. (2005). Application of a Holistic Model for Determining BPM Maturity. BP Trends, 2, $1-21$.

Rut, J. (2017). Production Process Optimization in the Researched Company. Marketing i Rynek, 7, 625-633.

Simanová, L., \& Gejdoš, P. (2015). The Use of Statistical Quality Control Tools to Quality Improving in the Furniture Business. Procedia Economics and Finance, 34, 276-283. doi: 10.1016/S22125671(15)01630-5

Sujova, A., \& Marcinekova, K. (2014). The Impact of Using Modern Process Performance Indicators on Financial Perormance of Woodworking Companies. Management of Companies, 4(1), 30-35.

Sujova, A., \& Marcinekova, K. (2015a). Modern Methods of Process Management Used in Slovak Enterprises. Procedia Economics and Finance, 23, 889-893. doi: 10.1016/S2212-5671(15)00381-0

Sujová, A., \& Marcineková, K. (2015b). Improvement of Business Processes - a Research Study in Woodprocessing Companies of Slovakia. Procedia Economics and Finance, 34, 296-302. doi: 10.1016/ S2212-5671(15)01633-0
Sujová, A., Simanová, L., \& Marcineková, K. (2016). Sustainable Process Performance by Application of Six Sigma Concepts: The Research Study of Two Industrial Cases. Sustainability, 8(3), 260-281. doi: 10.3390/ su 8030260

Sujova, A., Marcinekova, K., \& Hittmar, S. (2017). Sustainable Optimization of Manufacturing Process Effectiveness in Furniture Production. Sustainability, 9(6), 923-938. doi:10.3390/su9060923

Vickery, K. S., Dröge, C., \& Markland, R. E. (1997). Dimension of Manufacturing Strength in the Furniture Industry. Journal of Operations Management, 15(4), 317-330.

Zauskova, A., Miklencicova, R., Madlenak, A., Bezakova, Z., \& Mendelova, D. (2013). Environmental Protection and Sustainable Development in the Slovak Republic. European Journal of Science and Theology, 9(6), 153-154. 


\section{ANNEX: QUESTIONNAIRE 1}

Selected questions from the Questionnaire Change Management in Slovakia that were evaluated in the research paper (Questions: A, C, D, 4, 6, 11, 14, 16).

A. What is the average number of employees in your business?

(select one option)

$\square \quad 0$ to 10 employees

$\square \quad 11-20$ employees

$\square \quad 21$ - 50 employees

$\square \quad 51-250$ employees

$\square$ over 250 employees

C. What is the ownership of your business?

(select one option)

$\square$ net domestic capital

$\square \quad$ the domestic capital prevails

$\square$ foreign capital prevails

$\square$ net foreign capital

D. What was the ROE of your company in 2015 ?

(select one option)

negative value / $\mathrm{ROE}<0$ /

$\square$ positive value - from $0 \%$ to $2 \%$

$\square$ positive value - from $2 \%$ to $4 \%$

$\square$ positive value - from $4 \%$ to $7 \%$

$\square$ positive value - from $7 \%$ to $10 \%$

positive value - over $10 \%$

4. What types of changes have been made over the past ten years?

(multiple answers can be selected)

$\square$ financial restructuring

$\square$ transformational change restructuring

$\square$ radical re-engineering change

$\square$ gradual improvement

$\square$ incremental, i.e. unplanned but necessary changes

we did not make any changes

6. At what level do you optimise processes?

(select one option)

$\square$ optimisation options have been identified (we know areas that require improvement)

$\square$ we have a built-in mathematical model for calculating total costs up to delivery.

$\square$ employees have modern technology available to create efficient business processes. business standards and processes are linked to the identified business success factors and customer requirements.

we have a change management programme that ensures employee loyalty.

none of these options applies.

11. What analyses were made before the change was implemented, in its preparation?

(multiple answers can be selected)

$\square \quad$ SWOT analysis

$\square$ portfolio analysis

$\square$ field strength analysis (factors for and against change)

$\square$ financial analysis

$\square$ analysis of competition

$\square$ analysis of business processes

$\square$ satisfaction analysis and customer needs

$\square$ other (please specify):

14. What new concepts and methods have you used or employed to improve processes?

(multiple answers can be selected)

$\square$ Balanced Scorecard (BSC - Balanced Scorecard)

$\square$ Six Sigma

$\square$ process controlling

$\square \quad$ Total Quality Management (TQM)

$\square$ Kaizen (constantly improving business processes)

benchmarking

$\square$ we do not use any of these methods and concepts

other:

16. Do you use some of the following models to analyse and optimise processes?

(multiple answers can be selected)

$\square$ Diagnostic Reference Models (reference tables, relational databases, OLAP cubes)

$\square$ Information Models (ARIS, Matis, FirstStep, CimTool, IDEF, UML)

dynamic simulation (integration of fuzzy logic, genetic algorithms,

$\square$ integrated methods (GIM, SIM, GI-SIM, IMF-M methodology)

$\square$ other. Specify what:

$\square \quad$ we do not analyse business processes 